\title{
Pedagogical Approaches and the Impact of New Technologies on Teaching African History: Between a Didactic Revolution and Imagined Communities
}

\author{
Jean Philippe Ntede Edongo* \\ University of Douala-Cameroon
}

\author{
*Corresponding Author: Jean Philippe Ntede Edongo, University of Douala-Cameroon
}

\begin{abstract}
This study investigates the impact of education technology in the teaching of African History. It focuses on ways in which digital technology affects teaching practices in general and especially pedagogical content. Our goal is to delineate new spheres within which history could be better studied by future generations. In a prospective approach, the study purports to envision new pathways and innovative pedagogical practices for future centuries. In this investigation, four main research areas are explored: the use of computer and digital social media within education; the use of social media and academic changes; ways in which digital social media is perceived by educators at large, and current teachings on how to use social media. The study concludes that computers must remain tools and not overtake educators. Thus, digital technology is central to teaching African history, for as long as it is used to enhance teacher's capabilities.
\end{abstract}

Keywords: pedagogy, new technologies, didactics of history, educational system, social media practices, academic changes

\section{INTRODUCTION}

At the turn of the year 2000, we witnessed profound changes in pedagogical practices due to revolutionary advances in computer science (Castells: 1998). Computers and social media have opened up new and rich avenues allowing for a more active pedagogical approach to learning strategies (P. Fonkoua: 2006; Onguene Essono: 2009). More teachers and scholars are thus working together to shed light on the benefits and challenges brought by the advent of digital technologieswithin pedagogical approaches and methodologies (Anderson and Dron: 2011). And even though debates related to the writing of African history still rage on, the aim of our study is not to question the primacy of teaching history in African countries. In spite of this, it is difficult if not foolish not to acknowledge the interconnectedness of various parts of the world and its impact on our understanding of history. For this reason, the current study aims at opening up scholarly projects to this new environment (P. Fonjoua \& Béché: 2016).

While the Cameroonian government struggles to regulate the use of digital social media within the sphere of its educational system, it is imperative to understand how the teaching community integrates these new tools in their daily pedagogical activities. For what purpose do teachers and learners use these media? What is their aim? Can computers foster a better understanding of African history? What is at stake with the advent of these new technologies, of computer in particular, for teaching approaches and methodologies? What space does digital technology occupy in teaching practices? What are the pedagogical changes generated by the use of digital technology in the classroom? In short, "la question de l'arrimage du numérique à l'éducation est une préoccupation majeure" (P.F. Edongo Ntede, 2016). However, it is fair to wonder if innovation can simply be decreed. Do distributing free computers help the cause of advocating for better teaching practices and learning techniques? Should a good teacher always innovate? And are all innovations positive?

\section{MeTHOdOLOGY}

For this research, we use historical analysis because it is better suited to help grasp the use and the impact of new technologies within the Cameroonian educational system. As a discovery method, from records and accounts of what happened in the past or events, historical analysis asks us to consider 
various sources of historical data such as historical texts, reports in newspapers, diaries, and more. It has the advantage of helping us gain better insights into social phenomena and in our case teaching practices. A survey of multiple testimonies from teachers and students of the faculty of arts, letters and social sciences of the University of Yaounde 1 was conducted within this framework. Moreover direct observation of teachers' daily activities also took place.

These observations and individual survey interviews were conducted in ten (10) departments of that Faculty. Using an interview guide, participants responded to a questionnaire, and were able to describe their daily routine as well as their perceptions and representations regarding the use of computers. Four main axis of research were selected: 1) the use of computers and digital social media within education; 2) the use of social media and various changes in academia; 3) perceptions of digital social media by educators at large and 4) current teachings on how to use social media.

Case studies were also important to better reconstruct some teachers' experiences within this new and challenging context of digital technology. In short, an opinion poll was useful to our explanation of our research object. The goal was to investigate from the inside and more deeply statements related various teaching and learning behaviors. Data mining was thematically structured in order to facilitate their reading. Also, because of ethical issues, some informants were renamed in order to protect sensitive information linked to the University of Yaoundé I where many lecturers still rebuke the use of new evaluation techniques such as tele-assessment. The survey took place from November 62016 to February 272017.

\section{A SHORT HISTORIOGRAPHY OF COMPUTER ASSISTED INSTRUCTION}

Computer Assisted Instruction (CAI) appears very early at turn of the $20^{\text {th }}$ century with the industrial revolution marked by a massive exodus of the population towards cities and urban areas. This population is mainly lured by the prospect of new, better paid jobs. Training given to these new migrants also required more adequate teachers capable of educating mass workers. It is within this context that mechanizing training and instruction became a necessity.

In 1809, H. Chard invents a machine designed to booster teaching reading. He brands it and licenses it under the name of Mode of Teaching Reading. According to Lachance (1990:133), it is in 1809 that photography is used for the first in school in the United States (in Milwaukee). But it's only in 1913 that a personalized sequential teaching program is conceived. It is Edward Thorndike (1913), from Columbia University Teachers College who proposes to personalize instruction and invents the sequential approach. It's important to note that the development of computer programs in the field of education focused at first on individualized instruction and training. It's only later around 1958 that teaching through machines became generalized. It's within this context that Brian Skinner conceives a machine with teaching capabilities notably by storing teaching programs. The next year, IBM ${ }^{1}$ develops a Computer Assisted Instruction program for its own training purposes. In 1964, the company designs a cathodic screen adapted for Computer Assisted Instructions. And in 1966, it puts on the market a specially designed computer for CAI, namely the IBM 1500.

That said, a number of issues arise during its implementation: how to fully grasp the subject taught and validate unexpected answers; how do we decide what should be taught next; how to anticipate, diagnose and understand student error and false propositions; how to improve or modify current teaching strategies and learn new ones (Colbourn, 1985, trans. quoted by Pierre Bordeleau, 1994). In Cameroon, the introduction of computers in school is fairly recent and can be traced back to the 90s. Its process took several steps. At its beginning, it's a political decision taken in $2011^{2}$ by the Head of State and designed to encourage the creation of multimedia centers in high schools. Later on, this decision is boosted with the creation by the ENS (The Higher Teacher Training College) of Yaoundé,

\footnotetext{
${ }^{1}$ International Business Machines Corporation, an American multination company specialized in computer related technology and created on June 161991.

${ }^{2}$ Multimedia Centers of the Bilingual High School of Essos and of the Leclerc General High School were inaugurated by President Paul Biya on November 30 2001. At the end of the ceremony, a significant amount of computer equipment is put at the disposal of the Essos Bilingual High School in Yaoundé. Unfortunately, these multimedia centers are currently degraded and overcrowded.
} 
of a specialized program ${ }^{3}$ designed to train teachers in the field of Computer Assisted Instruction. The Computer Science department of the ENS of Yaoundé aimed at revolutionizing, by working closely with experts, the educational system by designing and implementing new didactic tools that could be applied in all fields and subjects.

\section{ENDOGENOUS USE OF COMPUTERS AND DIGITAL SOCIAL MEDIA IN EDUCATION}

There is no question that computers are increasingly part of the daily life of Cameroonians so much that in 2017, president Paul Biya distributed to each and every university student a laptop in a deal with the Chinese government who agreed to manufacture five hundred thousand (500000) specially designed laptops for basic academic tasks. Despite complaints ushered here and there with regards to the performance of these laptops, among others, the speed of its processor or its small storage capacity, this decision nonetheless testifies to the government commitment to adapt its teaching and learning environment to current technological advances. The fact that this laptop is affordable is no small feat and is definitely a plus in an environment where resources available to Cameroonian students are scarce.

Thus, it is evident that computers are extremely practical and useful when we consider the state of affairs in Cameroon but also when we take into account tasks that most define our contemporary life. Computers perform one the most important tasks of contemporary culture: access to information. Nevertheless, one cannot ignore its shortcomings and its dangers. For example, it is widely accepted that information obtained from the web is not always reliable and in the scientific field, that is the most sensitive issue scholars face. But with its interconnectedness, the benefits trump its dangers since access to information for example is far more important than the danger it brings. In that sense, computers facilitate scientific research and improve our daily life. The big question remains how computers and social media could be used as pedagogical tools.

\section{THE USE OF COMPUTERS AND SOCIAL MEDIA IN TEACHING AFRICAN HISTORY}

There are fundamental questions at play with regards to the use of computers and social media while teaching African History. First, what pedagogical practices should we prioritize in order to reach objectives set within the field (for example knowledge of historic sites, accounts/documents, oral/written, etc) while avoiding traditional teaching methods such as recitation? What traditional practices, methods and tools (manuals) should be kept in this new environment and for what purposes and goals new tools should be designed?

From our perspective, an efficient use of computers by students could generate great enthusiasm among younger teachers since the older generation is often skeptical about new technologies and their ability to positively impact teaching methods and practices. According to P.F. Edongo Ntede (2016):

Pour la plupart des enseignants, l'informatique est d'un apport considérable. Mais on observe que les outils technologiques sont plus utilisés par les plus jeunes. Les résultats montrent que l'utilisation des TICE est effective chez les jeunes enseignants (nouvelles recrues de 35 à 45 ans). Plus de $80 \%$ de jeunes enseignants intègrent l'informatique dans la préparation de leur cours. (P. F. Edongo Ntede, 2016) $)^{4}$. Ces ordinateurs pourraient avoir un impact significatif sur les résultats scolaires.

[For most teachers, computer science is highly beneficial to both teaching and learning. However, computer tools are mostly used by young people. Data show that the use of ICT in education is broadly effective with young teachers (freshly hired teachers aged from 35 to 45 ). More than $80 \%$ of young teachers include computers and computer related materials in course planning (P.F. Edongo Ntede, 2016). Thus,

\footnotetext{
${ }^{3}$ In September 2007, at the request of the Minister of Secondary Education, The Ministerof Higher Education created a major for teachers trained in Information and Communications Technology at the ENS of Yaoundé and it released its first pool in November 2009.

${ }^{4}$ "Appropriation des e-novations pédagogiques et éducation au Cameroun: Approches anthropologiques des mésusages du numérique à l'Université de Yaoundé I» In, Pierre FONKOUA \& Emmanuel BECHE, Les formations ouvertes et à distance au Cameroun. Entre discours et réalités d'innovation. Cahiers de recherche en éducation en collaboration avec l'UNESCO, 2016.
} 
these computers and computer related materials could have a huge impact on learning outcomes]

In fact, as a young history teacher, I believe there are many activities that could significantly improve teaching and learning the history of Cameroon. It is my view that teaching practices of Cameroonian history must be deeply transformed, modernized and updated so as to create a better understanding of its complexities and its richness. It goes without saying that the primary goal of teaching history is to provide students with tools allowing them to grasp the realities of their country within a very challenging global context and in which their role as actors is vital to its development.

Although history remains one of the most important and useful tools to think society at large, Cameroon seems to have been reluctant to take its own history by the horns and rethink itself. History teaches us that today's reality is always dependent upon past choices and thus today's choices will define our collective fate, and that in itself obliges us to put narratives at the core of our teaching of history. That said, the manipulation of history by some decision-makers can create social unrest. In this context, showing to students Cameroonian maps from 1884 to this date would certainly bring them closer to historical facts and realities and help them better understand what is at stake in current conflicts.

Thus, history as science must reach beyond its foundational principles to catch up with modern revolutions. The use of digital technology greatly contributes to better teaching practices within the discipline. Computers allow for better data collection and a playful atmosphere. By working with images, computer use in classrooms or amphitheaters opens up better social networks among students and teachers. It improves teacher delivery since computers are better suited for interactive approaches. Granted, computers are not the basic requirement to understanding history but their ability to connect via the Internet to a gigantic database constitutes a tremendous benefit to teaching and learning, especially when dealing with images.

Furthermore, within the main fields of history as discipline, namely the history of international relations, the history of civilization, of religions and Egyptology and economic and social history, the impact of digital technology on teaching practices is significant.

- In the History of International Relations, digital technology allows for a greater contact and exchange between various teaching pedagogies, it enables us to recognize more easily data linked to specific areas such as the conceptual study of international relations, different actors and diverse policies. An example: a showcase of images depicting an institutional actor in a conflict situation and more.

- Economic and social history use digital technology to advance the mastery of digital terminology and conceptual framework. It is used to better explain items such as curbs, tables, diagrams and images. In fact, digital technology brings learning with images to the center of the learning process and makes teaching more efficient.

- The History of civilizations, religions and Egyptology also make good use of digital technology. It facilitates visualization of pyramids and steles for example and partly solves the problem of field trips by exposing learners to real items they would otherwise only see by travelling to Egypt. By all means, with the history of civilizations and religions, digital technology opens up a completely new world to teachers and learners by transforming their interactions with their subject matter.

In practice, students usually need guidance and landmarks to adapt themselves to new and challenging environments (Jean Pierre Rioux). A landmark is an historical boundary marker similar to geodesic markers used to rebuild geographical spaces. In the field of History, it always comes down to acquiring important dates and patrimonial documents. Landmarks are fundamental to research and to the current political context. By putting aside dates related to events and historical figures mentioned in programs and teaching contents, we are driving ourselves to erasing African political history. By replacing or blurring these landmarks according to decision-makers, ethical questions arise and have the ability to erode the scientific premises on which history as a discipline is grounded. The study of the past is undoubtedly ingrained in the culture of a given people. This study could not be reduced to a list of dates and facts. The teaching of History allows every people to feel pride when looking back at historical figures and illustrious men who have profoundly shaped their destiny and their glory. 
Because of a context in which large population classes are the norm, it's even direr to transform teaching methods and practices, programs and didactic tools generally used. Computers could be more efficient when developing knowledge in the field of history and smoothen the learning process by encouraging research and data sharing on the Internet. Even though naysayers worry about online plagiarism and lack of originality, we believe developing a great awareness campaign would help create a research and digital culture in which computers are a plus and not a hindrance.

In fact, digital technology forces us to elaborate new teaching practices. The dual relationship between teacher and learner should be enriched by a new tool: the computer. Its advent will not replace the teacher but rather contribute to a successful learning process ${ }^{5}$.Computers expand both teacher and learner's scope and possibilities and students can only benefit from their use. It makes them more independent and puts them in charge of their learning processes, whether they work individually or in groups. Paradoxically, and contrary to commonly held beliefs, the use of computers actually makes teachers more irreplaceable since it brings them closer to students and makes them more available.

New technologies can also be an added value to new pedagogies. It will help transform students from an adult-centered position and from a dependency-complex in which the learner is characterized by its conformism, its lack or absence of individual initiative reducing pedagogy to a vertical relationship between an Adult-Teacher and a Child-Student. Rather, education must deconstruct the approach of pedagogy by leaning toward a better andragogical approach in which the learner, perceived as an adult, is defined by its autonomy. It is widely accepted today that traditional approaches to teaching strove by insisting on this vertical relationship between teacher and student since for them, learning is a downward action where knowledge goes from top (teacher) to bottom (student). The consequence is that learning is a process by which knowledge is assimilated by young people from experienced elders. As a result, critical thinking is controlled and negated to a great extent, affecting by the same token any attempt to change the system or the establishment.

The study via images of the History of Africa can help break from a series of stereotypes and clichés on Africa (famine, diseases and war constantly portrayed by western media outlets) and by the same token challenge current afro-pessimism. The challenge is to implement innovative pedagogical practices that shed a more positive light on a continent whose grading is always set at the bottom of the pile. New technologies will bring active pedagogies to the fore by focusing on students' needs and perhaps curb the massive rural exodus of populations fleeing wars and poor governance.

Although territorial and identity claims are not exclusive to Africa, its rich ethnic and cultural diversity coupled with its biodiversity make this continent a fertile ground for experimenting these new technologies. In this sense, teachers have the highest honor and duty to demonstrate how these new tools can impact how students feel about their origins and the pride it generate in them.

\section{EDUCATORS AND DIGITAL SOCIAL MEDIA}

During our interviews with teachers in the Department of History of the Faculty of Arts, Letters and Social Sciences of the University of Yaoundé, various positions regarding new technologies were registered. For M., 37 years old and Senior Lecturer, democratizing ICTs is vital:

Moi je crois que si tous les étudiants se procuraient des ordinateurs portables et qu'ils aient des cours adaptés afin d'en favoriser l'utilisation, ils pourraient rapidement acquérir l'esprit de recherche et surtout «la mentalité informatique». Non! Sincèrement je crois que le «don présidentiel » est une invite qu'il faut maximiser. Maintenant, comme vous le savez bien, on n'a pas donné les ordinateurs à tous les étudiants. Bon maintenant, il y a aussi et surtout le problème de la connexion wifi qui reste un hic !

[I strongly believe that if every student could have access to a laptop and that classed were adapted to meet this new environment, students would quickly acquire a research culture and more importantly a "computer mentality". No really! I truly

\footnotetext{
${ }^{5}$ Michel Antony. L'informatique : un outil pour l'histoire et la géographie. Bulletin de l'EPI (Enseignement Public et Informatique), Association EPI 1989, pp.161-183
} 
believe that the "presidential gift" should awaken our conscience and boost our incentives. Now, as you well know, not every student got a computer. But besides that, the next step is to provide internet connection to all these students!]

This position is not shared by a senior colleague, K, 58 and Associate Professor in the same department for whom:

Vous me faites rire avec vos histoires là ! Vous voulez juste favoriser le «copiécollé » et non la compréhension c'est tout ! Nous, on a quand même fait la même école ! Sommes-nous si bêtes? Vous copiez tout des blancs, même ce qui n'est pas adapté à notre milieu. Vos ordinateurs-là vont juste troubler les enfants en classe ! Regardez l'usage des téléphones portables dans les amphis, ça sonne partout ! On triche partout! Vous me faites rire! Avec ces outils, les étudiants apprendrons moins je vous assure. Mais, vous surveillez souvent les examens non? Qu'est-ce que vous remarquez ? On triche avec les téléphones !

[Don't make me laugh with this bull...! What this is going to create is a constant "copy-paste" attitude and hinder real efforts to understand a subject, that's all! We are not illiterate! Are we that stupid? You copy everything from the west, even things that adapted to our culture. These computers are just going to distract kids in class! Look at the use of cellphones in amphitheaters, they ring all the time! People cheat all the time! Don't make me laugh! With these tools, I can assure you that students will learn less. Anyway, don't you invigilate during exams? What do you see? People cheat with their cellphones!]

The position of this senior colleague is practically those of the same age group who reject basically all changes in teaching practices. For them, there is more misuse than benefit to gain from integrating new technologies in teaching practices. However, their position is challenged by T., expert in academic advising, scholar and professional with huge experience in the field:

Moi je pense plutôt que le meilleur moyen est de sensibiliser les jeunes dès leur première utilisation et de cette manière, ils seront plus conscients des dangers que peuvent engendrer une mauvaise utilisation de cette technologie. Avec le temps, ils seront capables d'utiliser leur jugement pour faire les bons choix et seront en mesure d'en assumer les conséquences. Il faut leur faire confiance. Il ne faut pas tout rejeter en bloc ! L'accès aux ordinateurs et la mise en place de programmes et de mesures adaptés est une bonne chose. La pédagogie est dynamique et non statique ! Et l'ordinateur est un outil pédagogique.

[I personally think that the best way to go about it is to create awareness among young people from their first use and thus make them more conscious of the dangers that come with an inappropriate use of these new devices. In time, they will be able to use their best judgement to decide how to use them and therefore be more responsible. We need to trust them. Don't reject systematically! Access to computers and implementation of new programs and adapted measures are a good thing. Pedagogy is dynamic and not static! The computer is a pedagogical tool.]

As an academic adviser, his position is definitive on this issue: the use of computers and new technologies in school is a necessity because our society has become technological in every single area. The question is how we educate its users. The goal is not to replace the latter. In History, computer technology will help share information between various groups when conducting practical work or assignments. For example, a database of the founding fathers of Cameroon could help students develop a critical eye on sensitive issues such as the unity of the country currently challenged by separatist movements of the two Anglophone regions. A topic such as the political or economic independence of Cameroon could be better discussed and understood.

In general, historians are avid practitioners of literature research. Software programs allow users to perform full text search with a title, an abstract and keywords. However, the lack of digital culture sometimes prevents students to appropriately select information or format it correctly. For young historians, there is a software that could be adapted to African or Cameroonian history: "J'ai vécu au XVIII ème siècle". 
This software has a dual use: look for data on a theme and create one or several social categories (possibility to work on the nature of selected documents); create a character and describe his social role, its activities. Simply put, rather than silencing the teacher, computers help correct and evaluate students' activities (it is in fact an instant evaluation system). If the Internet questions students' access to unlimited documentation, it also revives the debate surrounding teachers' place and responsibilities within contemporary educational systems and pedagogies. In the Anglophone Crisis for example, two radically opposed viewpoints are generally branded, each one looking to history for proofs to validate their claims. In this context, it is essential to initiate students to the process of applying the rules of evidence even though certain truths cannot be presented as cold hard facts.

For Michel Antony (1989) ${ }^{6}$, computer science can be approached from different angles in the field of History-Geography notably by conceiving specially designed programs (light software), as a personal tool for the teacher for whom it could be useful while elaborating his syllabus, or as a pedagogical and lecturing tool since it gives the teacher a platform to integrate other documents or curbs when analyzing data. A demonstration can be performed with the help of overhead projectors that enable students to see on a much bigger screen what was originally confined to the computer. By watching historical pictures of certain eras or sketched maps in order to better locate places where events occurred, teaching becomes more concrete because students almost touch learning topics. This new approach to teaching will undoubtedly help us depart from the psittacism that has always defined traditional teaching practices in the field of History. Student's memory will cease to be a simple storage where knowledge is practically dumped.

\section{EDUCATING ON THE USE OF SOCIAL MEDIA AND THE ADVENT OF THE FOAD}

FOAD (literally Open Long Distance Training) is a training setup that departs from the traditional face to face relationship between teacher and learner and moves to a more innovative design based on three poles: Teacher-Platform-Learner. Open Long Distance Training setups enable easier access to teaching materials without having to move. This setup is more adapted to a competency based approach since course content must be particularly designed to target specific abilities, and geared toward a very productive interaction between teacher and student.

Computers are pedagogical tools that need to be demystified because they are not just tools designed for information processing. Audio-visual aids constitute ways of reproducing sound and image for the benefit of teaching. That's a truism. Computer Assisted teaching of History is thus a working project and an innovative pedagogical process. It awakens learners' interest by showcasing documents or images. There is only one caveat as Pierre Fonkoua (2008) puts it in a paper titled "Approche conceptuelle de la ticeologie": integrating ICTs in teaching requires a systemic approach and a combination of disciplinary, psychopedagogical, technical and professional, didactic and managerial stakes. He suggests with M. Djeumeni (2016:254) that teaching assisted with new technologies "exige une profonde mutation dans les rôles et les tâches du formateur dont l'approche pédagogique devra être conçue désormais dans l'optique de la philosophie de l'autodidacte devant apprendre en autonomie » [requires meaningful changes in how teachers view their roles and their tasks so as to move pedagogical approaches from teacher-centered practices to student-centered methodologies, rendering the latter more autonomous and in charge of learning processes]

Computer science definitely brings so much to pedagogy and to the teaching of History today. With computer related tools, research is less strenuous. Interaction between scholars, teachers and learners is particularly more intense. Computers and the internet have significantly reduced the gap between teachers and learners. From a teaching standpoint, computer technology profoundly affects teaching practices and there is no doubt that a vast number of higher education teachers encourage its use and adapt it whenever possible to their pedagogy: As Béché and Fonkoua put it, "au Cameroun, l'engouement des acteurs politiques et éducatifs pour les $\mathrm{FOAD}^{7}$ est très marqué" [in Cameroon, there is great enthusiasm and drive, within the teaching community, for these FOAD] (Loiret, 2012. Tonye,

\footnotetext{
${ }^{6}$ Michel Antony, 1989, L'informatique : un outil pour l'histoire et la géographie. Bulletin de l'EPI (Enseignement Public et Informatique) №53, Association EPI 1989, pp.161-183

${ }^{7}$ Formation Ouverte et à Distance : it's an organized training framework that departs from the traditional face to face between teacher and student
} 
2010:15) ${ }^{8}$.In this environment, one is not surprised to notice the emergence of e-learning and of virtual electronic libraries therefore rendering research more feasible even for population with poor access to physical documents. With regards to research methods in history, computer technology offers the option to reclassify archives so that researchers have complete access to its database. Computer technology simplifies literature research. Classifying sources is greatly enhanced by software that alleviates the process of finding documents. As a result, learners have much quicker access to information and can find with greater precision documents related to their research. Furthermore, the use of computer technology allows for a confrontation of diverse sources of information and it's now possible to create an online research network in order to analyze historical sources related to the History of Africa in particular and the world in general.

\section{CONCLUSION}

This study purported to design new pathways to learning strategies and methodologies in the field of History for future generations. Using a prospective approach, the study aimed at thinking new avenues and innovative teaching practices that would be able to meet the challenges brought by future advances in human technology. Our inquiry shows that there ought to be a number of foundational principles that could guide our actions. The most important tenet is the fact that the use of computers in the Cameroonian educational system is a powerful tool to get students enthused about learning history and actively participating in the learning process. The computer is not a teaching machine per se but a tool at the disposal of both teacher and student and it should not enslave us but free us from the tyranny of some constraining traditional methods.

This study is a reminder of the important role innovation plays in teaching and learning philosophies and methodologies. As for Computer Assisted Instruction, it follows that the image can be both illustrative and a platform for thinking. Both approaches are not exclusive. Rather, they force us to ground historical narrative in a more concrete reality, more perceptible and more intelligible for students. Because students disconnect rather quickly when learning via abstract and theoretical discourses, an innovative pedagogy can bring them back at the center of the learning process and better assert an historical truth via colored images. It can also develop in them landmarks as well as a profound knowledge of patrimonial documents and ability to discuss major historical issues. This innovative approach does not change the place of the teacher who is still invested with the task of giving meaning to learning processes. Thus, his sense of pedagogical and didactic creativity remains useful when dealing with questions raised by students on current affairs.

What is required then is a constant dialogue between computer scientists and history teachers so as to prevent computers from being accused of overtaking human tasks and to make sure that beneficial projects are properly implemented without fear of endangering human nature. One would be mistaken to think that computers are a cure-all tool that could be used to solve all issues encountered in the Cameroonian educational system or all problems Cameroonians face daily. History should definitely be better known by the public. It is vital to develop in each and every student a sense of time ${ }^{9}$ by fightinga "western-centered" view in which our society tends to replace national heroes and founding fathers by short-lived stars and raises inertia as a national cultural artefact. Chronology and most important dates will cease to be simple historical sequels transformed into a vast knowledge that would do nothing but create disgust for history.

New technologies teach students adequate time management. Teaching practices integral to transmitting this science should adapt to our contemporary world so that learners could tackle major issues challenging today's world and organize their knowledge to gain access to true historical science, itself a template for understanding patriotism. For this reason, decentralized local communities should lean on historians to gain better insight on specific historical questions.

The outcome of this research could inform leaders, decision-makers and high-ranking officials and help them understand the value of ICTs in the Cameroonian educational system. In fact, results

\footnotetext{
${ }^{8}$ Béché E. \& Fonkoua P., Utilité, utilisabilité et acceptabilité de la formation ouverte et à distance en contexte universitaire camerounais, In Les formations ouvertes et à distance au Cameroun (2016).

${ }^{9}$ For most young people, the notion of time is elusive. For example, few students of this age group understand time as a continuum and past centuries as still connected to our present. They mostly distinguish the present from its recent past. Computer use has the ability to recreate memory by leaving traces of the past. From this standpoint, a pretty picture near to plain text on a screen makes it easier to understand.
} 
obtained here should help teachers and students have a clear insight on the epistemological and technological benefits of Computer Assisted Instruction.

\section{REFERENCES}

[1] Baldner, J.-M. et Marbeau, V. (1997), L'Histoire, la géographie et l'informatique, [History, Geography and Computer Science] CRDP de Poitou-Charentes.

[2] Bordeleau, P. (dir.) (1994). Des outils pour apprendre avec l'ordinateur. [Tools to learn with computers] Montréal : Éditions Logiques.

[3] Bruillard, E. (1997), Les machines à enseigner, [Teaching machines] Hermes, Paris.

[4] Castells, M.(1998), La société en réseau. L'ère de l'information. [A networking society. The information era] Paris, Fayard.

[5] Djeumeni, M. \& Fonkoua, P. (2016), «La FOAD au Cameroun: de la méfiance à la défiance »[FOAD in Cameroon : from fears to distrust] In, Pierre Fonkoua\& Emmanuel Beche, Les formations ouvertes et à distance au Cameroun. Entre discours et réalités d'innovation. [Open Long Distance Training in Cameroon. Between speeches and the challenges of innovation] Cahiers de recherche en éducation en collaboration avec l'UNESCO.

[6] Edongo Ntede, P. F. (2016), "Appropriation des e-novations pédagogiques et éducation au Cameroun: Approches anthropologiques des mésusages du numérique à l'Université de Yaoundé I»[Ownership of pedagogical e-novation and education in Cameroon : anthropological approaches of digital misuse at the University of Yaoundé 1] In, Pierre Fonkoua\& Emmanuel Beche, Les formations ouvertes et à distance au Cameroun. Entre discours et réalités d'innovation. [Open Long Distance Training in Cameroon. Between speeches and the challenges of innovation]Cahiers de recherche en éducation en collaboration avec l'UNESCO.

[7] Fonkoua, P. (dir.) (2006), Intégration des TIC dans le processus enseignement-apprentissage au Cameroun. [Integrating ICT in teaching-learning processes in Cameroon] Yaoundé : Terroirs.

[8] Fonkoua, P. \& Beche, E. (2016), Les formations ouvertes et à distance au Cameroun. Entre discours et réalités d'innovation,[Open Long Distance Training in Cameroon. Between speeches and the challenges of innovation] Cahiers de recherche en éducation en collaboration avec l'UNESCO, Paris.

[9] Loiret, P. J. (2012), (dir). Un détour par le futur : Les formations ouvertes et à distance à l'agence Universitaire de la Francophonie: 1992-2012. [Turning to the future: Open Long Distance Training in the Francophonie University Association] in Paris: Editions Contemporaines.

[10] Michel Antony (1989), L'informatique : un outil pour l'histoire et la géographie. [Computer Science : a tool for History and Geography] Bulletin de l’EPI (Enseignement Public et Informatique) N53, Association EPI 1989, pp.161-183.

[11] Onguene Essono, L-M. (2009), L'insertion des TIC à l'école: L'exemple du ROCARE et des centres des ressources multimédias scolaires. [Integrating ICT at school ; the case of ROCARE and high school multimedia centers] EuroAfrica-ICT. Communication présentée au Colloque R\&D de l'UE.

[12] Pouts-Lajus, S. Et Riche-Magnier, M. (1998), L'École à l'heure d'Internet, [School in the age of the Internet] Paris, Nathan.

[13] Rapport de l'Inspection générale de l'Éducation nationale, 2002, «L'École et les réseaux numériques »,[School and Digital Networks] visited on the website IGEN.

[14] Tonye, E. (2010). Modélisation d'un dispositif pour la formation ouverte et à distance dans les pays africains subsahariens. [Modelling a design for Open Long Distance Training in Subsahara Africa] Frantice.net, 2, 72-85.

\section{AUTHOR'S BIOGRAPHY}

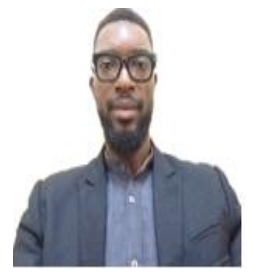

Born on 05 May 1986 in Yaounde (Cameroon), Jean Philippe NTEDE EDONGO studied at the University of YaoundeI. PhD. D in Economic and Social History of a thesis supported under the direction of Professor Philippe Blaise Essomba. For several years as a temporary lecturer in the Department of History at the University of Yaounde I (Cameroon), he is currently a permanent lecturer at the Faculty of Arts and Humanities (FLSH) at the University of Douala (Cameroon). Research focuses on economic history, social history, transport history, education history, digital history.

Citation: Jean Philippe Ntede Edongo. “Pedagogical Approaches and the Impact of New Technologies on Teaching African History: Between a Didactic Revolution and Imagined Communities”. International Journal of History and Cultural Studies (IJHCS). vol 5, no. 2, 2019, pp. 21-29. doi: DOI: http://dx.doi.org/ 10.20431/2454-7654.0502002.

Copyright: (c) 2019 Authors. This is an open-access article distributed under the terms of the Creative Commons Attribution License, which permits unrestricted use, distribution, and reproduction in any medium, provided the original author and source are credited. 